\title{
AN ECONOMIC STUDY OF LOW LYING INLAND FISH FARMING IN SELECTED AREAS OF KISHOREGANJ DISTRICT
}

\author{
M. Taj Uddin' ${ }^{1}$ and Israt Farjana ${ }^{2}$ \\ Department of Agricultural Economics, Bangladesh Agricultural University \\ Mymensingh-2202, Bangladesh
}

\begin{abstract}
The study was designed to examine the low lying inland fish farming practices of Karimganj upazila under Kishoreganj districts. Field level data were collected through direct interview using semi-structured questionnaire. Eighty sample farmers were selected purposively from the study areas. Six types of farming practices were identified in the study area among which only two types were prominent i.e., pond fish farming and Beel fish farming. Tabular, statistical and mathematical analyses were done to achieve the major objectives. The benefit cost ratio in Beel fish farming was 2.86 and in case of pond fish farming it was 1.95. Multiple regression model was used to explain the variation of gross return of pond and Beel fish farming and it was found that coefficients of human labour, feed, cowdung and manure had significant impact on gross return, whereas coefficients of feed, harvesting and making sanctuary had significant impact on gross return of Beel fish farming. Resource use efficiency was calculated by the ratio of marginal value product and marginal factor cost. Finally, the study identified some important problems of low lying inland fish farming and suggested probable solutions relating to the problems.
\end{abstract}

Key Words: Pond fish farming, Beel fish farming, BCR, Resource use efficiency

\section{INTRODUCTION}

Bangladesh is blessed with vast fisheries resources due to favorable climatic condition and geographical location of the country. The country is dominated by floodplains and rivers, which are rich ecosystems for freshwater fish. The floodplains that cover a good portion of the country, are inundated annually during the monsoon season where agriculture and natural fisheries complement one another. In the monsoon to post-monsoon season (JuneNovember), the floodplains provide an ideal habitat for the wide diversity of wild fish species, whereas in the dry season, the land is cultivated with rice.

1Professor and 2Ex-master's student, Department of Agricultural Economics, Bangladesh Agricultural University, Mymensingh-2202, Bangladesh. The paper has been developed from the first author's research project (No. 2011/20/AU-GC) funded by BAURES, Mymensingh-2202 
Fisheries as one of the sub-sector of agriculture has been playing very significant role in supplying nutrition, creation of rural employment, poverty reduction and earning foreign exchange and more importantly socioeconomic stability in the rural areas of Bangladesh. Throughout the centuries, fish has been an important component of the people's diet in many parts of the world. Moreover, most of the people in Bangladesh depend on fish for their animal protein and fish provides 63.00 percent of animal protein consumption (Rahman, 2009). They fisheries sub-sector contributes 5.38 percent of Gross Domestic Product (GDP) (BER, 2012). Bangladesh earns a significant amount of foreign currency, i.e., 4.90 percent of total export earning from fisheries products (BBS, 2009). The export of fishery products such as frozen shrimp, live fish, dry fish, salted fish, fish maw, shark-fin, tortoise and turtles is increasingly emerging as a prominent economic activity. In our country, the natural annual fish production cannot meet the increasing demand of the human population which is resulting pressure on aquaculture to enhance the production. Continuous efforts are being made to increase fish production from locally available sources. Bangladesh has a great potentiality to increase inland fish production. To fulfill the deficit of animal protein, there is crying need to cultivate quick growing fish under scientific methods and management.

However, the study is expected to generate baseline information on socioeconomic characteristics of fish farmers, costs and return of low lying inland fish farming. The study is also expected to add valuable information about factors responsible for the variation of gross return and resource use efficiency. Indeed, a good number of socioeconomic studies on pond fish culture are available but knowledge on the socioeconomic aspects of fish culture in low lying inland water bodies is not plentiful. Therefore, a study on low lying inland fish farming has been felt urgently needed in order to assess its productivity, profitability and resource use efficiency from the viewpoint of farmers.

\section{METHODOLOGY}

The study was designed to address the prominent low lying inland fish farming practices in some selected areas of Karimganj Upazila under Kishoreganj district. Six types of fish farming practices were found in the study area among which only two types were prominent i.e., pond fish farming and Beel fish farming. Other four farming practices were river, ditch, crop field and canal fish farming. Field level data were collected in January 2012 through direct interview. As the population was large and considering the limited time, efforts and fund eighty samples were selected. Ideally, ponds for multipurpose use are a common feature of the countryside, they are even more common on flood-free land as they are secured from flood damage. These excavated ponds (formerly termed as tanks) are a major source of the higher value fishes. On the other hand, Beels are water bodies which are largely used as agricultural land in the dry season but in the wet season it is largely used as fishery (Banglapedia, 2003).

The proportion of pond fish farming type in the total sample was 37.50 percent. In Beel fish farming, two types of management practices were found i.e., single ownership and joint 
ownership. The proportion of single ownership and joint ownership were 31.25 percent and 10.00 percent, respectively. The average size of Beel fish farm and pond fish farm were 1.21 ha and 0.15 ha, respectively.

Table 1. Distribution of sampled farmers in the study area

\begin{tabular}{lccc}
\hline \multicolumn{1}{c|}{ Types of fish farming } & No. of respondents & Percentage (\%) \\
\hline River & 3 & 3.75 \\
Pond & 30 & 37.50 \\
Beel & Single ownership & 25 & 31.25 \\
& Joint ownership & 8 & 10.00 \\
Ditch & 5 & 6.25 \\
Crop field & 5 & 6.25 \\
Canal & 4 & 5.00 \\
\hline Total & 80 & 100.00 \\
\hline
\end{tabular}

Source: Field Survey, 2012

Tabular, statistical and mathematical techniques were applied to achieve the objectives of the study. Moreover, per hectare profitability of inland fish production from the view point of individual farmers was measured in terms of gross return, gross margin, net return and benefit cost ratio (undiscounted). Functional analysis was employed to show the individual effect of input use and other related factors of fish culture with the help of multiple regression model. The following form of the model was used:

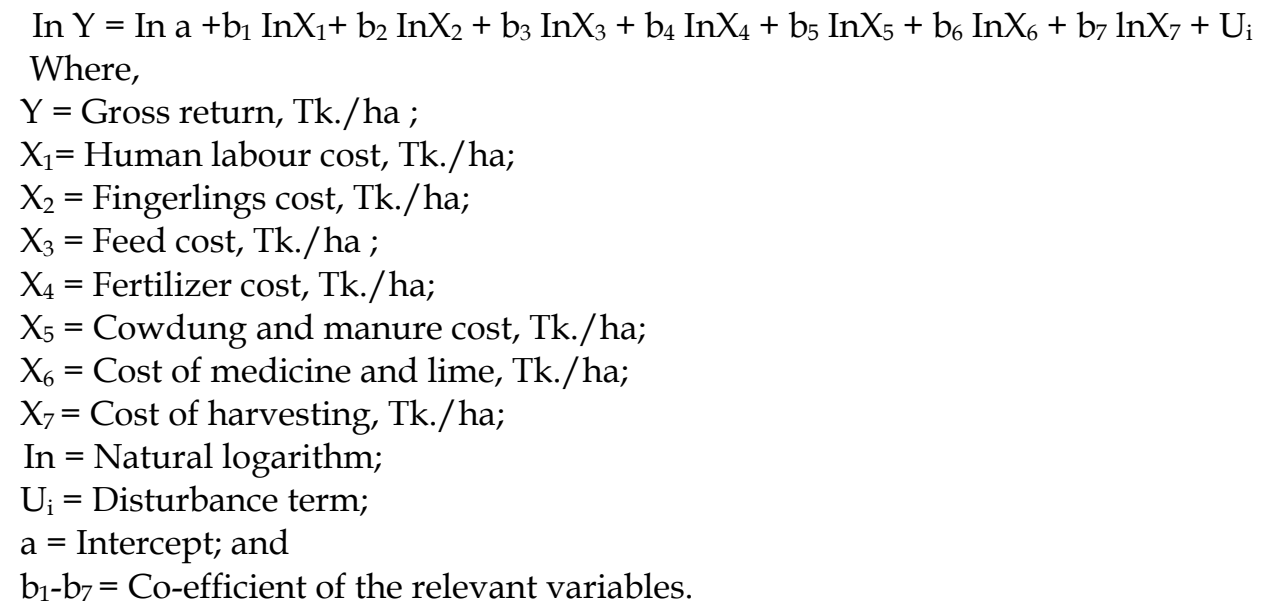

In order to measure resource use efficiency, ratio of marginal value product (MVP) and marginal factor cost (MFC) was calculated. Resources are considered to be efficiently used when the ratio of approaches one, or MVP and MFC for each input were equal. When the marginal physical product (MPP) is multiplied by the product price, the marginal value 
product (MVP) is obtained. Marginal factor cost (MFC) is the price of one unit of input. The optimum use of a particular input would be ascertained by the condition of equality of MVP and MFC, i.e.,

$$
\frac{M V P x_{i}}{M F C x_{i}}=1
$$

The MVP of a particular resource represents the addition to gross returns in value terms resulting from an addition of one unit of that resource while other inputs are held constant. The most reliable, perhaps the most useful estimate of MVP is obtained by taking resources $\left(\mathrm{X}_{\mathrm{i}}\right)$ as well as gross return $(\mathrm{Y})$ at their geometric means. Since the seven variables of regression model were measured in monetary value, the slope coefficient of these explanatory variables in the function represented the MVPs, which were calculated by multiplying the production co-efficient of given resources with the ratio of geometric mean (GM) of gross return to the geometric mean (GM) of the given resources, i.e.,

$$
\begin{aligned}
& \ln \mathrm{Y}=\operatorname{lna}+\mathrm{b}_{\mathrm{i}} \ln \mathrm{X}_{\mathrm{i}} \\
& \mathrm{dY} / \mathrm{dX}_{\mathrm{i}}=\mathrm{b}_{\mathrm{i}} \mathrm{Y} / \mathrm{X}_{\mathrm{i}} \\
& \text { Therefore, MVP }\left(\mathrm{X}_{\mathrm{i}}\right)=\mathrm{b}_{\mathrm{i}} \quad \frac{\bar{Y}(G M)}{\bar{X}_{i}(G M)} \\
& \text { Where, } \\
& \mathrm{Y}=\text { Mean value }(\mathrm{GM}) \text { of gross return in taka; } \\
& \mathrm{Xi}=\text { Mean value }(\mathrm{GM}) \text { of the ith variable input in taka; } \\
& \mathrm{GM}=\text { Geometric mean; and } \\
& \mathrm{dY} / \mathrm{dX} \mathrm{X}_{\mathrm{i}}=\text { Slope of the production function as well as MVP of ith input. }
\end{aligned}
$$

\section{RESULTS AND DISCUSSION}

\section{Socioeconomic profile of the fish farmers}

In the present study the sample farmers were classified into three age groups such as 5.0015.00 years, 15.00-55.00 years and above 55.00 years (HIES, 2010). It was found that out of the total sample farmers, 18.75 percent belonged to the age group of 5.00-15.00 years old. About 62.50 percent of fish farmers were in $15.00-55.00$ years age group (Table 2). About 18.75 percent of fish farmers fell into above 55 years age group. The literacy level is generally considered as an index of social advancement of the community. From the literacy point of view, fish farmers were classified into four groups, i.e., primary level, secondary level, higher secondary level and graduate and above. It is revealed from the table 3 that level of education of fish farmers up to primary, secondary, higher secondary and graduation were 37.50 percent, 31.25 percent, 23.75 percent and 7.50 percent, respectively. 
Table 2. Age distribution of sample farmers in the study areas

\begin{tabular}{l|c|c}
\hline \multicolumn{1}{c|}{ Age group (years) } & No. & Percentage (\%) \\
\hline $5.00-15.00$ & 15 & 18.75 \\
$15.00-55.00$ & 50 & 62.50 \\
Above 55.00 & 15 & 18.75 \\
\hline Total & 80 & 100.00 \\
\hline
\end{tabular}

Source: Field survey, 2012

Table 3. Educational status of sample respondents

\begin{tabular}{lcc}
\hline \multicolumn{1}{c}{ Level of education } & No. of respondents & Percentage (\%) \\
\hline Primary & 30 & 37.50 \\
Secondary & 25 & 31.25 \\
Higher Secondary & 19 & 23.75 \\
Graduate and above & 6 & 7.50 \\
\hline Total & 80 & 100.00 \\
\hline
\end{tabular}

Source: Field survey, 2012.

From the view point of profession, 8.75 percent sample farmers took fish farming as main occupation. It was found that average farm size of fish farmers was 0.75 ha. Average own cultivable land of sample farmers was 0.55 ha which was 73.33 percent of total land. It is also observed from the table 4 that average homestead area and pond size of fish farmers were 0.25 and 0.15 ha.

Table 4. Land distribution of sample farmers

\begin{tabular}{lcc}
\hline \multicolumn{1}{c|}{ Utilization of land } & Area (ha) & Percentage (\%) \\
\hline Homestead area & 0.25 & 33.33 \\
Pond & 0.15 & 20.00 \\
Own cultivable land & 0.55 & 73.33 \\
Rented-in/ leased-in & 0.65 & 86.67 \\
Rented-out/Leased-out & 0.80 & 106.66 \\
\hline Total & 0.75 & 100.00 \\
\hline
\end{tabular}

Source: Field Survey, 2012

\section{Cost and return of low lying inland fish farming}

Productivity means yield per hectare from a fish farm. It was calculated by summing yield of different fish species. It was obtained that per hectare yield of fish in pond fish and Beel fish farming were $305.82 \mathrm{~kg}$ and $378.85 \mathrm{~kg}$, respectively. The cost items were identified as human labor, fingerlings, feed, fertilizer, cowdung and manure, lime and medicine, harvesting and making sanctuary, land use cost, depreciation and interest on operating 
cost etc. In the study area, most of the fingerlings are brought from the local area with the current price. Human labour cost was an important factor in the production process. Cost of human labour in pond and Beel fish farming were estimated at Tk. 4,005.75 and Tk. 4,068.43 per hectare which represents 4.52 percent and 17.11 percent of total cost, respectively.

Table 5 reveals that cost of fingerling was Tk. 6,358.70 per hectare and represent 23.06 per cent of total cost in pond fish farming. On the other hand, in Beel fish farming, cost of fingerling was Tk. 1,024.29 per hectare which represented 4.30 per cent of total cost. Per hectare cost of feed for pond and Beel fish farming were Tk. 9,741.82 and Tk. 3,415.31, respectively and their corresponding percentages were 35.33 and 14.36. Similarly, cost of harvesting and making sanctuary in pond and Beel fish farming were Tk. 1,080.50 and Tk. $8,685.87$ per hectare, respectively which shared 3.91 and 36.53 percent of total cost. The estimated costs of interest on operating cost for pond and Beel were Tk. 1,419.19 and Tk. 1,118.57, respectively which consisted 5.14 and 4.70 percent of total cost. Considering all the sample farmers, per hectare land use cost for pond and Beel fish farming were Tk. 1,919.19 and Tk. 2,817.78 which shared 6.90 and 11.85 percent of total cost, respectively. Total cost of production of pond fish farming and Beel fish farming were estimated at Tk. 27,571.94 and Tk. 23,779.23 per hectare, respectively.

Table 5. Per hectare cost of fish production in pond and Beel fish farming

(Tk./year)

\begin{tabular}{l|cc|cc}
\hline \multirow{2}{*}{ Cost items } & \multicolumn{2}{|c|}{ Pond fish farming } & \multicolumn{2}{c}{ Beel fish farming } \\
\cline { 2 - 5 } & Cost (Tk.) & Percentage (\%) & Cost (Tk.) & Percentage (\%) \\
\hline Human labor & $4,005.75$ & 14.52 & $4,068.43$ & 17.11 \\
Fingerlings & $6,358.70$ & 23.06 & $1,024.29$ & 4.30 \\
Feed & $9,741.82$ & 35.33 & $3,415.31$ & 14.36 \\
Fertilizer & 618.01 & 2.24 & 201.70 & 0.85 \\
Cowdung and manure & 633.01 & 2.29 & 256.54 & 1.08 \\
Lime and medicine & 526.00 & 1.90 & 102.44 & 0.43 \\
Harvesting and making sanctuary & $1,080.50$ & 3.91 & $8,685.87$ & 36.53 \\
Miscellaneous & 689.42 & 2.50 & 888.30 & 3.74 \\
Interest on operating cost & $1,419.19$ & 5.14 & $1,118.57$ & 4.70 \\
\hline Total variable cost & $25,072.41$ & - & $19,761.45$ & - \\
\hline Land use cost & $1,919.19$ & 6.90 & $2,817.78$ & 11.85 \\
Depreciation of farm implements & 580.34 & 2.10 & $1,200.00$ & 5.05 \\
\hline Total fixed cost & $2,499.53$ & - & $4,017.78$ & - \\
\hline Total cost & $27,571.94$ & 100.00 & $23,779.23$ & 100.00 \\
\hline Source Anthry
\end{tabular}

Source: Anthor's estimation based on field survey, 2012 
Productivity of Beel fish farming is higher than pond fish farming. It was found from the table 6 that gross return from pond and Beel fish farming were Tk. 53,833.20 and Tk. 68,075.25, respectively. Gross margin were estimated at Tk. 28,760.79 and Tk. 48,313.80 for pond and Beel fish farming, respectively and their corresponding net returns were estimated at Tk. 26,261.26 and Tk. 44,296.02. The benefit cost ratio in Beel fish farming was 2.86 and in case of pond fish farming it was 1.95. The BCR of pond fish farming of the present study is almost close to the study of Uddin and Takeya (2005) who found the highest benefit cost ratio (2.15) for the pond fish enterprise among all agricultural enterprises such as crop, cattle, poultry and pond fish farming.

Table 6. Per hectare cost and return in pond and Beel fish farming

\begin{tabular}{|c|c|c|}
\hline Particulars & Pond fish farming & Beel fish farming \\
\hline Yield (kg) & 305.82 & 378.85 \\
\hline Gross returns (GR) & 53833.20 & 68075.25 \\
\hline Total variable cost (TVC) & 25072.41 & 19761.45 \\
\hline Total fixed cost (TFC) & 2499.53 & 4017.78 \\
\hline Total cost $(\mathrm{TC})=(\mathrm{TVC}+\mathrm{TFC})$ & 27571.94 & 23779.23 \\
\hline Gross margin $(\mathrm{GM})=(\mathrm{GR}-\mathrm{TVC})$ & 28760.79 & 48313.80 \\
\hline Net return $(\mathrm{NR})=(\mathrm{GR}-\mathrm{TC})$ & 26261.26 & 44296.02 \\
\hline $\mathrm{BCR}$ (Undiscounted) $=(\mathrm{GR} / \mathrm{TC})$ & 1.95 & 2.86 \\
\hline
\end{tabular}

Source: Anthor's estimation based on field survey, 2012

\section{Resource use efficiency}

To determine the effect of explanatory variables on gross return, following production function for pond fish production was obtained:

$$
\begin{aligned}
\ln Y= & 0.832+0.297 \ln X_{1}+0.697 \ln X_{2}+0.185 \ln X_{3}-0.054 \ln X_{4}+0.218 \ln X_{5}+0.081 \ln X_{6} \\
& (1.555) \quad(0.134) \quad(0.358) \\
- & 0.077 \ln X_{7} \\
& (0.089)
\end{aligned}
$$

Production function for Beel fish production was obtained as follows:

$\ln Y=5.285+0.299 \ln X_{1}+0.272 \ln X_{2}+0.271 \ln X_{3}-0.152 \ln X_{4}+0.077 \ln X_{5}-0.016 \ln X_{6}$

$$
\begin{aligned}
& \begin{array}{lllll}
(1.940) & (0.402) & (0.205) & (0.118) & (0.160)
\end{array} \quad \text { (0.182) } \\
& +0.294 \ln X_{7}
\end{aligned}
$$$$
(0.143)
$$

Note: Figures within parentheses indicate the standard error

The estimated value of the coefficient of human labor cost was 0.297 in pond fish farming which was positive and significant al 5 percent probability level. It indicates that, 1 percent increase in human labor cost, on an average, led to 0.297 percent increase in gross return for pond fish farmers, holding other variables constant. In pond fish farming, coefficient of 
human labor, feed and cowdung and manure had significant impact on gross return. In case of Beel fish farming, coefficient of feed and harvesting and making sanctuary had significant impact on gross return. The F-values of the model derived from pond and Beel fish farming were 17.712 and 9.592, respectively, which were significant at 5 percent probability level implying that all the included explanatory variables included in the model were important for explaining the variation in gross return under both types of fish farming. The estimated value of goodness of fit, $\mathrm{R}^{2}$ of the model was 0.709 and 0.838 for pond and Beel fish farming, respectively. The estimated values of the adjusted $\mathrm{R}^{2}$ of the model were 0.669 and 0.750 for pond fish farming and Beel fish farming, respectively.

The summation of all the regression coefficients of the estimated model gives information about the returns to scale, that is, the response of output to the proportionate change in all inputs. The value of returns to scale were estimated as 1.350 and 1.045 for pond fish farming and Beel fish farming, respectively. It indicates that there is an ample scope for further increase in input use for more production both for pond and beel fish farming.

In pond fish farming, it was observed from table 7 that ratios of MVP and MFC for human labour $\left(X_{1}\right)$, fingerlings $\left(X_{2}\right)$, feed $\left(X_{3}\right)$, cowdung and manure $\left(X_{5}\right)$, lime and medicine $\left(X_{6}\right)$ were greater than one which indicates these inputs were underutilized in the production process. So, more return may be obtained by increasing the level of use of these resources. It was also observed that ratios of MVP and MFC for fertilizer $\left(\mathrm{X}_{4}\right)$, harvesting and making sanctuary $\left(X_{7}\right)$ were less than one which indicates that these inputs were over utilized. That means, excessive use of these inputs would reduce gross return.

Table 7. Marginal value products of different resources in fish farming

\begin{tabular}{l|c|c|c|c|c|c}
\hline \multicolumn{1}{c|}{ Variables } & \multicolumn{3}{c|}{ Pond fish farming } & \multicolumn{3}{c}{ Beel fish farming } \\
\cline { 2 - 7 } & $\begin{array}{c}\text { Co- } \\
\text { efficient }\end{array}$ & $\begin{array}{c}\text { Geome- } \\
\text { tric } \\
\text { Mean }\end{array}$ & MVPs & $\begin{array}{c}\text { Co- } \\
\text { efficient }\end{array}$ & $\begin{array}{c}\text { Geome- } \\
\text { tric } \\
\text { Mean }\end{array}$ & MVPs \\
\hline Human labour cost $\left(\mathrm{X}_{1}\right)$ & $0.297^{* *}$ & 13367.95 & 3.07 & 0.299 & 16596.12 & 34.47 \\
Fingerlings cost $\left(\mathrm{X}_{2}\right)$ & 0.697 & 8462.57 & 11.41 & 0.272 & 15748.03 & 2.80 \\
Feed cost $\left(\mathrm{X}_{3}\right)$ & $0.185^{* *}$ & 39116.20 & 1.95 & 0.271 ** & 29518.61 & 1.49 \\
Fertilizer cost $\left(\mathrm{X}_{4}\right)$ & -0.054 & 557.23 & -13.42 & -0.152 & 476.79 & -51.80 \\
Cowdung and manure $\left(\mathrm{X}_{5}\right) \operatorname{cost}\left(\mathrm{X}_{5}\right)$ & $0.218^{*}$ & 876.57 & 34.47 & 0.077 & 506.07 & 24.72 \\
Lime and medicine cost $\left(\mathrm{X}_{6}\right)$ & 0.081 & 2011.33 & 5.58 & -0.016 & 540.57 & -4.80 \\
Cost of harvesting and making & -0.077 & 1580.22 & -6.75 & $0.294^{* * *}$ & 3992.40 & 11.97 \\
sanctuary $\left(\mathrm{X}_{7}\right)$ & & & & & & \\
\hline
\end{tabular}

Source: Author's calculation, 2012

In case of Beel fish farming, it was observed that ratios of MVP and MFC for human labor $\left(X_{1}\right)$, fingerlings $\left(X_{2}\right)$, feed $\left(X_{3}\right)$, cowdung and manure $\left(X_{5}\right)$ and harvesting and making sanctuary $\left(\mathrm{X}_{6}\right)$ were greater than one which means these inputs were underutilized. That 
means, more return may be obtained by increasing the level of use of these resources. But ratios of MVP and MFC for fertilizer $\left(X_{4}\right)$, lime and medicine $\left(X_{6}\right)$ were less than one that means these resources were over utilized. So, more return may be obtained by decreasing the level of use of these resources.

\section{Problems and probable solutions}

Farmers faced various problems in culturing fish. Some major problems were identified as: non-availability and high price of quality fingerlings (16.25 percent respondent), low price of output (18.75 percent), high price of inputs (31.25 percent), non-availability of credit facilities (25.00 percent), lack of scientific knowledge (22.50 percent), lack of extension services (31.25 percent), multiple ownership (6.25 percent), etc. Likely, sampled farmers put forward some suggestions for solving the problems, such as, availability of labour and other inputs with reasonable prices, to develop easy procedure in loan with a lower interest rate, to reduce price fluctuation of fishes in the marker, to improve transport and marketing facilities and so on.

\section{CONCLUSION}

The study revealed some valuable information regarding low lying inland fish farming. The overall findings of this research suggest that both pond and Beel fish farming are profitable. The benefit cost ratio and the net return both are higher in Beel fish farming (BCR 2.86 and net return Tk. 44,296.02) than pond fish farming (BCR 1.95 and net return Tk. 26,261.26). From multiple regression model for pond fish farming, it was observed that coefficients of human labour, feed, cowdung and manure had significant impact on gross return, whereas coefficients of feed, harvesting and making sanctuary had significant impact on gross return in Beel fish farming. This implies that a farmer could enhance profit by investing more on fish production. Rahman and Talukdar (2001) found that pond fish production could be increased by increasing the size of the pond. On the other hand, Sarker and Islam (2011) concluded that Koi fish production can be increased by improving the production technology and knowledge in existing pond fish culture. However, if the problems are removed and fish producers are given incentives, fish farming in low lying areas could improve income generation, employment creation and poverty reduction; and thereby may contribute to the overall economic development of the country.

\section{REFERENCES}

Banglapedia. 2003. National Encyclopedia of Bangladesh, Asiatic Society of Bangladesh, Dhaka, Bangladesh, 6: 17-18.

BBS. 2009. Statistical Yearbook of Bangladesh, Bangladesh Bureau of Statistics, Ministry of Planning, Government of the People's Republic of Bangladesh, Dhaka.

BER. 2012. Bangladesh Economic Review, Finance Division, Ministry of Finance, Government of the People's Republic of Bangladesh, Dhaka. 
HIES. 2010. Household Income and Expenditure Survey. Bangladesh Bureau of Statistics, Ministry of Planning, Government of the People's Republic of Bangladesh, Dhaka.

Rahman, M. A. 2009. Year round pangus and food security: An economic analysis of some selected areas of Mymensingh district. An unpublished M. S. Thesis, Department of Agricultural Economics, Bangladesh Agricultural University, Mymensingh.

Rahman, M. L. and Talukder, R. K. 2001. Interlinkages of agricultural diversification in Bangladesh. Centre on Integrated Rural Development for Asia and the Pacific, Dhaka.

Sarker, M. R. and Islam, M. S. 2011. An economic study of small scale Koi (Anabas Testudineus) Fish farming in some selected areas of Greater Mymensingh district. Bangladesh Journal of Political Economy, 27(1\&2): 287-295.

Uddin, M. T. and Takeya, H. 2005. Economic analysis of integrated farming by agricultural enterprise in Mymensingh District of Bangladesh. Journal of Development Studies, 16(1), 40-49. 